The $6^{\text {th }}$ Conf. of SSFOP “Sustainable Development of Ornamental, Medicinal and Aromatic

Plants Scope”, Cairo, Egypt, 1/3/2020

Scientific J. Flowers \& Ornamental Plants

www.ssfop.com/journal

ISSN: 2356-7864

doi: 10.21608/sjfop.2020.91394

\title{
GROWTH AND ESSENTIAL OIL ANALYSIS OF OCIMUM BASILICUM, L. PLANTS AS AFFECTED BY SEAWEED EXTRACT AND ACTIVE DRY YEAST
}

\author{
A.H. El-Naggar; M.R.A. Hassan and A.M. Saeid \\ Floriculture, Ornamental Horticulture and landscape Gardening Dept., Fac. of Agric., (EL-Shatby), \\ Alexandria Univ. Egypt
}

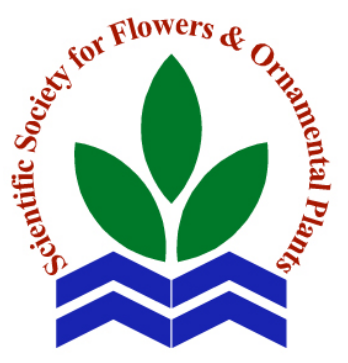

Scientific J. Flowers \& Ornamental Plants, 7(1):27-43 (2020).

Received: $13 / 1 / 2020$

Accepted: $10 / 2 / 2020$
ABSTRACT: This study was carried out in the Nursery of Floriculture, Ornamental Horticulture and Landscape Gardening Department, Faculty of Agriculture, Alexandria University, during the two successive seasons of 2017 and 2018. The aim of the present investigation was to evaluate the effect of seaweed extract and active dry yeast on vegetative growth and oil yield of Ocimum basilicum L. The layout of the experiment of both seasons was split-plot design in three replicates. Each replicate contained 20 different treatments (4 levels of dry yeast x 5 levels of seaweed) five plants were used as a plot for each treatment. The main plot represented the active dry yeast at the concentrations of $0,2,4$ and $6 \mathrm{~g} / \mathrm{l}$ which sprayed on plant leaves. The sub-plot was seaweed extract at the concentrations of $0,1,2,3$ and $4 \mathrm{~g} / \mathrm{l}$ added as a foliar application. The most of vegetative growth and yield traits responded significantly to the combination of active dry yeast with seaweed extract as biofertilizer on basil plants. Plant height, number of leaves, leaves dry weights and leaf area were significantly affected with spraying plants by dry yeast and seaweed. As a general, the treatment namely $6 \mathrm{~g} / \mathrm{l}+4 \mathrm{~g} / \mathrm{l}$ gave the best combination between the dry yeast and seaweed. The best oil percentage was recorded by using $4 \mathrm{~g} / \mathrm{l}$ dry yeast with $4 \mathrm{~g} / \mathrm{l}$ seaweed in the first cuts of both seasons and by using $6 \mathrm{~g} / \mathrm{l}$ dry yeast with $4 \mathrm{~g} / \mathrm{l}$ seaweed in the second cuts in both seasons. The major components of sweet basil essential oil were linalool, giving the highest percentage (52.16-79.55\%) by using $6 \mathrm{~g} / \mathrm{l}$ dry yeast with control $(0 \mathrm{~g} / \mathrm{l})$ seaweed. Estragole, recorded the highest percentage (5.14-11.79\%) by using $6 \mathrm{~g} / \mathrm{l}$ dry yeast with $1 \mathrm{~g} / \mathrm{l}$ seaweed. Eucalyptol, gave the highest percentage (1.54-9.72\%) by using $4 \mathrm{~g} / \mathrm{l}$ dry yeast with $2 \mathrm{~g} / \mathrm{l}$ seaweed. Methyl cinnamate, the highest percentage (1.12-10.37\%) was produced by using $0 \mathrm{~g} / \mathrm{l}$ dry yeast with $4 \mathrm{~g} / \mathrm{l}$ seaweed. Tau-cadinol, the highest percentage (1.01-6.97\%) was obtained by using 2 g/l dry yeast with 2 g/l seaweed. Trans- $\alpha-$ bergamotene, the highest percentage (1.23-5.18\%) was resulted by using $0 \mathrm{~g} / \mathrm{l}$ dry yeast with $0 \mathrm{~g} / \mathrm{l}$ seaweed. Bornyl acetate, gave the highest percentage (1.12-4.53\%) was obtained by using 2 g/l dry yeast with $4 \mathrm{~g} / \mathrm{l}$ seaweed. Form this study we recommend economically and environmentally to fertilize sweet basil by spray bio fertilization as dry yeast at the rate 4 or $6 \mathrm{~g} / \mathrm{l}$ with spray the plants by seaweed at the rate 4 


\section{A.H. El-Naggar et al.}

g/l to obtain the best growth, oil yield, and safe for human being chemical composition of Ocimum basilicum L.

Key words: Medicinal and aromatic plants, Ocimum basilicum, L., seaweed extract, essential oil, dry yeast, basil.

\section{INTRODUCION}

Ocimum comprises several aromatic and medicinal Lamiaceae herbs belonging to different species at least 65 species (Paton et al., 1999) of herbs and shrubs from the tropical and sub-tropical regions of Asia, Africa, Central and South America. The main center of diversity appears to be Africa.

Ocimum basilicum, L. is an annual herb with $50-60 \mathrm{~cm}$ in height with leaves color from green to purple and pink and with small white or pink flowers. (Sharafzadeh and Alizadeh, 2011). Basil has been planted as a popular culinary and medicinal herb (Bilal et al., 2012) from ancient time until now and the leaves and flowers have been used for the treatment of headaches, coughs, diarrhea, worms and kidney malfunctions, as well as for its carminative, galactagogue, stomachic and antispasmodic properties. Pripdeevech et al. (2010) reported that the dominant components of essential oil were methyl chavicol (81.82\%), $\beta$-(E)-ocimene (2.93\%), $\alpha-(E)$-bergamotene $(2.45 \%), \quad \alpha$-epi-cadinol (2.08\%), 1,8-cineole (1.62\%), methyl eugenol (1.10\%), and camphor (1.09\%). In the field experiment that was conducted to assess yield, oil content, and composition of 38 genotypes of $O$. basilicum, the availability of various chemotypes or individual compounds such as linalool, eugenol, methyl chavicol (estragole), methyl cinnamate, or methyl eugenol offers the opportunity for production of basil to meet the market requirements of specific basil oils.

Bio-fertilizers are reasonably safer to the environment and play an important role in decreasing the use of chemical fertilizers. Consequently, it causes a reduction in environmental pollution. Bio fertilizers are microbial inoculants consisting of living cells of micro-organism like bacteria, algae and fungi alone or combination which may help in increasing crop productivity. Bio fertilizers can influence plant growth directly through the production of phytohormones such as gibberellins, cytokinins and IAA that act as growth regulators and indirectly through nitrogen fixation and production of bio-control agents against soil-borne phytopathogens and consequently increase formation of metabolites which encourage the plant vegetative growth and enhance the meristematic activity of tissues to produce more growth (Ahmed and Kibret, 2014)

Seaweeds are green, brown and red marine macroalgae. Extracts of brown seaweeds are widely used in horticulture crops largely for their plant growthpromoting effects and for their ameliorating effect on crop tolerance to abiotic stresses such as salinity, extreme temperatures, nutrient deficiency and drought. The chemical constituents of seaweed extract include complex polysaccharide, fatty acids, vitamins, phytohormones and mineral nutrients growth promoting hormones (IAA and IBA), cytokinins, trace elements ( $\mathrm{Fe}, \mathrm{Cu}$, $\mathrm{Zn}, \mathrm{Co}, \mathrm{Mo}, \mathrm{Mn}, \mathrm{Ni}$ ) and amino acids. (Battacharyya et al., 2015). The seaweeds resources are intensively used to improve harvest quantity and quality in agriculture and horticulture. So, themain objectiveof thepresent investigation was to evaluate the individual and combined effects of seaweed extract and dry yeast on growth parameters, quantity and quality of the essential oil of Ocimum basilicum L. var. "Genovese” under Egypt conditions.

\section{MATERIALS AND METHODS}

The present work was carried out during the two successive seasons of 2017 and 2018 at the Nursery of the Department of the Floriculture, Ornamental Horticulture and Landscape Gardening, Faculty of 
Agriculture, Alexandria University, Egypt. Seeds of basil (Ocimum basilicum, L. var. "Genovese") were supplied from National Research Center, Dokki, Giza, Egypt. Seeds were sown on $25^{\text {th }}$ February 2017 and $20^{\text {th }}$ March 2018 in the first and second seasons, respectively, in a sandy clay loam soil and seed pans were used. After one month from sowing, when the seedling reached $8-10 \mathrm{~cm}$. height with 6:8 leaves and 4 branches, they were transplanted to final claypots $30 \mathrm{~cm}$. in diameter filled with a mixture of clay, sand and cattle manure $(2: 1: 1 \mathrm{v} / \mathrm{v} / \mathrm{v})$. Physical and chemical properties of the growing media used in the study are presented in (Table 1). Seaweed extract used was powder of Ascophyllum nodosum (Acadian). The chemical composition of Acadian extract powder is shown in Table (2).

Seaweed extract treatments at the concentrations of $0,1,2,3$ and $4 \mathrm{~g} / \mathrm{l}$ were added as a foliar application one day after irrigation till run-off. The plants were sprayed four times, the first one after 15 days from the final transplanting, the second one after 15 days from the first, while the third was applied after the first harvest and the fourth was 15 days after the thirdspraying. The active dry yeast Saccharomyces cerevisiae treatments at the concentration
0,2,4 and $6 \mathrm{~g} / \mathrm{l}$ were sprayed on plant leaves after one week of spraying times with seaweed (Omer et al, 2016). The yeast suspension was prepared by dissolving the ADY and sugar together $(1: 1 \mathrm{w} / \mathrm{w})$ in warm water (about $35-37{ }^{\circ} \mathrm{C}$ ) and kept at room temperature for 12 hours before spraying to enhance yeast activity (Shalaby and ElNady,2008).Herb harvest was taken place, in the first cut when inflorescence shoots occurred (50\% flowering) in July and after two months the second cut harvest was done in September in both seasons. All the plants were harvested at a height of $10 \mathrm{~cm}$. above the ground (Mohamed et al, 2016).

The experiment was contained three replicates, each replicate contained 20 treatments (4 levels of dry yeast x 5 levels of seaweed) five plants were used as a plot for each treatment. Data were statistically analyzed using split-plot design in 2017 and 2018 seasons. The main plot represented the active dry yeast, while, the seaweed extract concentrations were occupied in sub-plots. Comparisons between means of the studied treatments were carried out using least significant difference at 0.05 probability level (L.S.D $\mathrm{D}_{0.05}$ ) according to Gomez and Gomez (1984).

Table 1. Physical and chemical analysis of the chosen growing media.

\begin{tabular}{|c|c|c|c|c|c|c|c|c|c|c|c|c|c|c|c|}
\hline \multicolumn{16}{|c|}{ Physical properties } \\
\hline \multirow{2}{*}{\multicolumn{2}{|c|}{$\begin{array}{c}\text { Clay } \\
20.5 \% \\
\end{array}$}} & \multirow{2}{*}{\multicolumn{4}{|c|}{$\begin{array}{c}\text { Silt } \\
3.90 \% \\
\end{array}$}} & \multirow{2}{*}{\multicolumn{7}{|c|}{$\begin{array}{c}\text { Sand } \\
75.6 \% \\
\end{array}$}} & \multirow{2}{*}{\multicolumn{3}{|c|}{$\begin{array}{c}\text { Soil texture } \\
\text { Sandy clay loam }\end{array}$}} \\
\hline & & & & & & & & & & & & & & & \\
\hline \multicolumn{16}{|c|}{ Chemical properties } \\
\hline \multirow{2}{*}{$\begin{array}{c}\mathrm{EC} \\
\mathrm{dSm}^{-1}\end{array}$} & \multirow{2}{*}{$\mathbf{p H}$} & \multirow{2}{*}{$\begin{array}{c}\mathrm{CaCO}_{3} \\
\%\end{array}$} & \multicolumn{3}{|c|}{$\begin{array}{l}\text { Macronutrients } \\
\text { (ppm) }\end{array}$} & \multicolumn{4}{|c|}{ Micronutrients (ppm) } & \multicolumn{3}{|c|}{ Cations (meq./l) } & \multicolumn{3}{|c|}{ Anions (meq./l) } \\
\hline & & & $\mathbf{N}$ & $\mathbf{P}$ & $\mathbf{K}$ & $\mathbf{C u}$ & $\mathbf{F e}$ & Mn & Zn & $\mathbf{N a}^{+}$ & $\mathbf{M g}^{++}$ & $\mathrm{Ca}^{+}$ & SO4- - $^{-}$ & $\mathrm{HCO}_{3}^{--}$ & $\mathrm{Cl}^{-}$ \\
\hline 2.11 & 8.2 & 21 & 60 & 4.3 & 308 & 0.39 & 4.22 & 4.57 & 1.62 & 16 & 3.5 & 2.9 & 7.9 & 4.3 & 6.8 \\
\hline
\end{tabular}

Table 2. The chemical composition of Acadian marine plant extract powder from Ascophyllum nodosum.

\begin{tabular}{|c|c|c|c|}
\hline \multicolumn{2}{|c|}{ Guaranteed minimum analysis } & \multicolumn{2}{|c|}{ Physical properties } \\
\hline Total nitrogen $(\mathrm{N})$ & $0.7 \%$ & NPK and minerals (ash) & $45 \%-55 \%$ \\
\hline Available phosphoric acid $\left(\mathrm{P}_{2} \mathrm{O}_{5}\right)$ & $0.2 \%$ & Moisture & Max 6.5\% \\
\hline Soluble potash $\left(\mathrm{K}_{2} \mathrm{O}\right)$ & $17 \%$ & Alginic acid & Min $10 \%$ \\
\hline & & Mannitol & Min 4\% \\
\hline & & Amino acids & Min 4\% \\
\hline & & Other organic matter & Min 20\% \\
\hline
\end{tabular}




\section{A.H. El-Naggar et al.}

The Vegetative growth parameters included; plant height $(\mathrm{cm})$, leaf number, leaves dry weights (g) and leaf area $\left(\mathrm{cm}^{2}\right)$, The essential oil was extracted by water distillation method according to Novak et al. (2002). The amount of oil obtained from five plants was measured and oil percentage (\%) was calculated according to Charles and Simon (1990). Volatile oil percentage was calculated using the following equation:

Volatile oil $\%=$ Oil volume in the graduated tube/weight of leaves sample $(\mathrm{g}) \times 100$.

Oil yield/plant $=$ Oil percentage $\times$ leaf fresh weight per plant/100.

Chemical constituents of essential oil of leaves were analyzed using the Trace GC Ultra/Mass Spectrophotometer ISQ (Thermo Scientific) (GC/MS) apparatus. GC/ MS analysis was done in Central Lab of National Institute of Oceanography and Fisheries, Alexandria, Egypt. The main chemical components of the oil are linalool, estragole, eucalyptol, methyl cinnamate, tau-cadinol, trans- $\alpha$-bergamotene, bornyl acetate.

\section{RESULTS AND DISCUSSION}

Effect of seaweed extract, dry yeast and their interaction on vegetative growth of Ocimum basilicum plants:

\section{Plant height:}

Data presented in Tables (3 and 4) showed that spraying basil plant with dry yeast at all studied rates (2,4 and $6 \mathrm{~g} / \mathrm{l})$ gave no significant effect in plant height for the first and second cuts in both seasons. For the effect of seaweed, there were a significant effect on basil plant height compared with control but in the second cut of the first season, there was no significant effects between all the treatments of seaweed. In the first cut, there was a significant effect between seaweed levels, and the highest value $(44.03 \mathrm{~cm})$ was obtained by spraying the plants with the seaweed at rate $4 \mathrm{~g} / \mathrm{l}$. Furthermore, in the second season, there was a significant effect of seaweed treatments on plant height in both harvesting and the highest values were recorded from treated plants with $4 \mathrm{~g} / \mathrm{l}$ seaweed $(70.08,72.99 \mathrm{~cm})$, respectively.

Concerning the interaction, there was a significant effect on plant height in both cuts of the two seasons. The best results were obtained with the combination between $6 \mathrm{~g} / \mathrm{l}$ dry yeast and $3 \mathrm{~g} / \mathrm{l}$ seaweed $(45.62 \mathrm{~cm})$ in the first cut of the first season while in the second cut, it was $6 \mathrm{~g} / \mathrm{l}$ dry yeast and $2 \mathrm{~g} / \mathrm{l}$ seaweed $(52.10 \mathrm{~cm})$. In the first cut of the second season was $4 \mathrm{~g} / \mathrm{l}$ dry yeast with $4 \mathrm{~g} / \mathrm{l}$ seaweed $(73.07 \mathrm{~cm})$ while in the second cut, it was $6 \mathrm{~g} / \mathrm{l}$ dry yeast with $4 \mathrm{~g} / \mathrm{l}$ seaweed $(81.23 \mathrm{~cm})$. On the other side, the shortest plants were obtained from using the treatment of $2 \mathrm{~g} / \mathrm{l}$ dry yeast with $0 \mathrm{~g} / \mathrm{l}$ of seaweed for the first cut of the first season with value of $38.94 \mathrm{~cm}$, and by using of $2 \mathrm{~g} / \mathrm{l}$ dry yeast with $2 \mathrm{~g} / \mathrm{l}$ seaweed for the second cut of the first season with value of 42.51 $\mathrm{cm}$.

The beneficial effect of active dry yeast foliar application on growth traits plants may be due to that yeast as a natural source of cytokinins had stimulatory effects on cell division and elongation, protein and nucleic acids synthesis and chlorophylls formation (Spencer et al., 1983). Also, yeast was found to contain carbohydrate, amino acids and lipids, several vitamins and most nutritional elements. Also, growth enhancement by seaweed extracts may be due to components such as macro and micro elements, amino acids, vitamins, cytokinins, auxins and abssisic acid (ABA)-like growth substances which affect cellular metabolism in treated plants leading to enhanced growth and crop yield (ÖrdÖg et al., 2004). Cytokinins cause enhancement of cell size and cell division and were effective on shoot formation (Sivasangari et al., 2015).

\section{Number of leaves/plant:}

From the data presented in Tables (5 and 6 ) it was indicated that the best results were obtained from treating plants with dry yeast at the rate of $6 \mathrm{~g} / \mathrm{l}$ with values of 274.71, 328.85 and 349.10 leaves/plant, respectively. The second cut of the second season has the 
Table 3. Effect of seaweed extract, dry yeast treatments and their combinations on the plant height (cm) of Ocimumc basilicum plants in the first season (2017).

\begin{tabular}{|c|c|c|c|c|c|c|}
\hline \multirow{2}{*}{ Dry yeast (A) g/l } & \multicolumn{5}{|c|}{ Seaweed extract (B) g/l } & \multirow{2}{*}{ Mean } \\
\hline & $\mathbf{0}$ & 1 & 2 & 3 & 4 & \\
\hline \multicolumn{7}{|c|}{ First cut } \\
\hline $\mathbf{0}$ & 40.38 & 41.56 & 42.27 & 42.67 & 43.36 & 42.05 \\
\hline 2 & 38.94 & 43.75 & 43.48 & 41.15 & 43.02 & 42.07 \\
\hline 4 & 44.55 & 39.92 & 41.51 & 42.10 & 45.13 & 42.64 \\
\hline 6 & 43.50 & 43.44 & 43.00 & 45.62 & 44.62 & 44.04 \\
\hline Mean & 41.84 & 42.17 & 42.56 & 42.89 & 44.03 & \\
\hline L.S.D 0.05 & \multicolumn{2}{|c|}{$A=N . S$} & \multicolumn{2}{|c|}{$\mathrm{B}=1.399$} & \multicolumn{2}{|c|}{$\mathrm{A} \times \mathrm{B}=2.797$} \\
\hline \multicolumn{7}{|c|}{ Second cut } \\
\hline $\mathbf{0}$ & 44.70 & 42.89 & 50.45 & 48.14 & 45.83 & 46.40 \\
\hline 2 & 47.50 & 46.56 & 42.51 & 48.35 & 50.17 & 47.02 \\
\hline 4 & 47.96 & 45.21 & 45.12 & 48.10 & 49.49 & 47.18 \\
\hline 6 & 42.82 & 51.00 & 52.10 & 46.07 & 47.85 & 47.97 \\
\hline Mean & 45.74 & 46.42 & 47.55 & 47.67 & 48.33 & \\
\hline L.S.D 0.05 & \multicolumn{2}{|c|}{$A=N . S$} & \multicolumn{2}{|c|}{$B=N . S$} & \multicolumn{2}{|c|}{$\mathrm{A} \times \mathrm{B}=4.747$} \\
\hline
\end{tabular}

N.S = Not significant at the level of probability of 0.05 .

Table 4. Effect of seaweed extract, dry yeast treatments and their combinations on the plant height (cm) of Ocimum basilicum plants in the second season (2018).

\begin{tabular}{|c|c|c|c|c|c|c|}
\hline \multirow{2}{*}{ Dry yeast (A) g/l } & \multicolumn{5}{|c|}{ Seaweed extract (B) g/l } & \multirow{2}{*}{ Mean } \\
\hline & $\mathbf{0}$ & 1 & 2 & 3 & 4 & \\
\hline \multicolumn{7}{|c|}{ First cut } \\
\hline $\mathbf{0}$ & 53.40 & 62.16 & 63.75 & 70.93 & 72.50 & 64.55 \\
\hline 2 & 59.95 & 59.85 & 70.66 & 61.98 & 70.73 & 64.63 \\
\hline 4 & 68.29 & 68.21 & 61.21 & 64.66 & 73.08 & 67.09 \\
\hline 6 & 65.87 & 68.13 & 68.50 & 69.48 & 64.03 & 67.20 \\
\hline Mean & 61.88 & 64.59 & 66.03 & 66.76 & 70.08 & \\
\hline L.S.D 0.05 & \multicolumn{2}{|c|}{$A=N . S$} & \multicolumn{2}{|c|}{$B=3.304$} & \multicolumn{2}{|c|}{$A \times B=6.608$} \\
\hline \multicolumn{7}{|c|}{ Second cut } \\
\hline $\mathbf{0}$ & 58.03 & 62.10 & 69.87 & 72.94 & 68.42 & 66.27 \\
\hline 2 & 62.62 & 71.30 & 67.54 & 66.14 & 66.60 & 66.84 \\
\hline 4 & 63.65 & 67.35 & 70.30 & 65.70 & 75.73 & 68.55 \\
\hline 6 & 73.22 & 68.18 & 64.19 & 71.87 & 81.23 & 71.74 \\
\hline Mean & 64.38 & 67.23 & 67.97 & 69.16 & 72.99 & \\
\hline L.S.D 0.05 & \multicolumn{2}{|c|}{$\mathrm{A}=\mathrm{N} . \mathrm{S}$} & \multicolumn{2}{|c|}{$\mathrm{B}=5.131$} & \multicolumn{2}{|c|}{$A \times B=10.262$} \\
\hline
\end{tabular}

N.S = Not significant at the level of probability of 0.05 . 
A.H. El-Naggar et al.

Table 5. Effect of seaweed extract, dry yeast treatments and their combinations on number of leaves per plant of Ocimum basilicum plants in the first season (2017).

\begin{tabular}{|c|c|c|c|c|c|c|}
\hline \multirow{2}{*}{ Dry yeast (A) g/l } & \multicolumn{5}{|c|}{ Seaweed extract (B) g/l } & \multirow{2}{*}{ Mean } \\
\hline & $\mathbf{0}$ & 1 & 2 & 3 & 4 & \\
\hline \multicolumn{7}{|c|}{ First cut } \\
\hline $\mathbf{0}$ & 242.55 & 218.73 & 212.50 & 204.50 & 241.10 & 223.88 \\
\hline 2 & 250.23 & 250.38 & 257.33 & 280.50 & 267.53 & 261.19 \\
\hline 4 & 253.67 & 251.13 & 271.17 & 277.70 & 285.00 & 267.73 \\
\hline 6 & 228.13 & 280.55 & 278.72 & 271.70 & 314.43 & 274.71 \\
\hline Mean & 243.64 & 250.20 & 254.93 & 258.60 & 277.02 & \\
\hline L.S.D 0.05 & \multicolumn{2}{|c|}{$A=16.749$} & \multicolumn{2}{|c|}{$B=16.904$} & \multicolumn{2}{|c|}{$\mathrm{A} \times \mathrm{B}=33.808$} \\
\hline \multicolumn{7}{|c|}{ Second cut } \\
\hline $\mathbf{0}$ & 252.73 & 355.80 & 307.15 & 318.80 & 384.28 & 293.51 \\
\hline 2 & 301.20 & 246.20 & 339.87 & 302.20 & 278.10 & 323.75 \\
\hline 4 & 362.25 & 327.75 & 305.53 & 304.65 & 337.70 & 327.58 \\
\hline 6 & 283.78 & 333.13 & 331.80 & 359.35 & 336.20 & 328.85 \\
\hline Mean & 299.99 & 315.72 & 321.09 & 321.25 & 334.07 & \\
\hline L.S.D 0.05 & \multicolumn{2}{|c|}{$A=25.152$} & \multicolumn{2}{|c|}{$B=N . S$} & \multicolumn{2}{|c|}{$\mathrm{A} \times \mathrm{B}=55.771$} \\
\hline
\end{tabular}

N.S = Not significant at the level of probability of 0.05 .

Table 6. Effect of seaweed extract, dry yeast treatments and their combinations on number of leaves per plant of Ocimum basilicum plants in the second season (2018).

\begin{tabular}{|c|c|c|c|c|c|c|}
\hline \multirow{2}{*}{ Dry yeast (A) g/l } & \multicolumn{5}{|c|}{ Seaweed extract (B) g/l } & \multirow{2}{*}{ Mean } \\
\hline & $\mathbf{0}$ & 1 & 2 & 3 & 4 & \\
\hline \multicolumn{7}{|c|}{ First cut } \\
\hline $\mathbf{0}$ & 311.67 & 273.33 & 266.08 & 312.83 & 296.83 & 292.15 \\
\hline 2 & 263.33 & 311.33 & 276.50 & 305.00 & 436.56 & 318.54 \\
\hline 4 & 297.83 & 319.67 & 353.11 & 291.00 & 332.50 & 318.82 \\
\hline 6 & 286.83 & 331.33 & 355.50 & 445.33 & 326.50 & 349.10 \\
\hline Mean & 289.92 & 308.92 & 312.80 & 338.54 & 348.10 & \\
\hline L.S.D 0.05 & \multicolumn{2}{|c|}{$A=44.234$} & \multicolumn{2}{|c|}{$B=27.743$} & \multicolumn{2}{|c|}{$\mathrm{A} \times \mathrm{B}=55.485$} \\
\hline \multicolumn{7}{|c|}{ Second cut } \\
\hline $\mathbf{0}$ & 306.33 & 369.50 & 381.33 & 424.22 & 374.00 & 371.08 \\
\hline 2 & 333.00 & 408.50 & 348.33 & 382.17 & 494.75 & 393.35 \\
\hline 4 & 303.33 & 390.50 & 386.33 & 470.83 & 432.50 & 396.70 \\
\hline 6 & 391.33 & 366.33 & 449.22 & 428.89 & 441.00 & 423.74 \\
\hline Mean & 333.50 & 383.71 & 391.31 & 426.53 & 435.56 & \\
\hline L.S.D 0.05 & \multicolumn{2}{|c|}{$A=N . S$} & \multicolumn{2}{|c|}{$\mathrm{B}=33.331$} & \multicolumn{2}{|c|}{$\mathrm{A} \times \mathrm{B}=66.662$} \\
\hline
\end{tabular}

N.S = Not significant at the level of probability of 0.05 . 
same trend but without a significant difference. Meanwhile, the least numbers of leaves/plant were obtained from using the treatment of $0 \mathrm{~g}$ dry yeast/l (control) in the two cuts of the first season and the first cut of the second season with values of 223.88, 293.51 and 292.15 leaves/plant, respectively.

Furthermore, spraying basil plants with all levels of seaweed caused increases in number of leaves per plant in the first cut of the first season and both cuts of the second season compared with control plants. The highest numbers of leaves were obtained from using the treatment of $4 \mathrm{~g} / \mathrm{l}$ with values of 277.02, 348.10 and 435.56 leaves/plant, respectively. The second cut of the first season has the similar trend but without a significant difference. On the other hand, there was no significant difference between the treatment of $3 \mathrm{~g} / \mathrm{l}$ and the treatment of 4 $\mathrm{g} / \mathrm{l}$ of the first cut of the first season and both cuts of the second season.

For to the interaction among the dry yeast and seaweed treatments, there was significant effect in the two cuts of the two seasons. The best results were obtained from using the treatment of $6 \mathrm{~g} / \mathrm{l}$ dry yeast with 4 $\mathrm{g} / \mathrm{l}$ seaweed for the first cut of the first season with value of (314.43 leaves/plant), the treatment of $0 \mathrm{~g} / \mathrm{l}$ dry yeast with $4 \mathrm{~g} / \mathrm{l}$ seaweed in the second cut of the first season which afforded value of 384.28 leaves/plant, the treatment namely $2 \mathrm{~g} / \mathrm{l}$ dry yeast with 4 $\mathrm{g} / \mathrm{l}$ seaweed for the second cut of the second season with value of 494.75 leaf /plant, and treatment namely $6 \mathrm{~g} / \mathrm{l}$ dry yeast with $3 \mathrm{~g} / \mathrm{l}$ seaweed for the first cut of the second season with value of 445.33 leaf/plant. These results attributed to the effect of yeast in increasing levels of endogenous hormones in treated plants, which could be interpreted by cell division and cell elongation (Khedr and Farid, 2002). The increment in number of leaves/plant treated with seaweed extract may be due to the increased vigorous plant growth, i.e. plant height and number of branches in these plants, in addition to the plant growth regulators that direct improve growth. These results are in the same line with those obtained by Mohamed (2015) on Ocimum basilicum.

\section{Leaves dry weight (g):}

Data presented in Tables (7 and 8) revealed that the highest value was obtained with treating basil plants with $6 \mathrm{~g} / \mathrm{l}$ dry yeast with values of 4.81, 4.51, 5.45 and 5.31 g/plant, respectively. Moreover, the best results were recorded when treated plants with $4 \mathrm{~g} / \mathrm{l}$ seaweed with values of 5.29 and 5.35 g/plant, respectively. The two cuts of the first season have the similar trend but without a significant difference. The least dry weight results were obtained from using seaweed at the level of control treatment (0 $\mathrm{g} / \mathrm{l})$ with values of 4.47 and $4.13 \mathrm{~g} / \mathrm{plant}$, respectively for the two cuts of the second season.

Concerning the interaction between dry yeast and seaweed treatments for leaves dry weight, generally, there was significant effect in the both cuts of the two seasons. The best results were obtained with the treatment of $6 \mathrm{~g} / \mathrm{l}$ dry yeast with $4 \mathrm{~g}$ seaweed/l in the both harvests of the both seasons with values of 5.60, 5.35, 6.82 and $6.34 \mathrm{~g} /$ plant, respectively. Generally, the least results were obtained by using the treatment of $0 \mathrm{~g} / \mathrm{l}$ dry yeast (control treatment) with $0 \mathrm{~g} / \mathrm{l}$ seaweed (control) with values of 3.65 and 3.15 g/plant respectively. This increment in dry weight due to active dry yeast and seaweeds application may be attributed to the general increased growth expressed as number of shoots and fresh weight/plant which is the reason behind the high dry matter obtained.

The results agree with those of Moghith (2016) on Origanum vulgare and Ragab (2016) on African marigold.

\section{Leaf area $\left(\mathrm{cm}^{2} /\right.$ plant)}

Data presented in Tables (9 and 10) showed that the most effective treatment was $6 \mathrm{~g} / \mathrm{l}$ dry yeast with the following values in both cuts in the both seasons 1631.37, 1296.39, 1122.24 and $1603.16 \mathrm{~cm}^{2} /$ plant, respectively. For the seaweed treatments, also there was significant effect on leaf area 
A.H. El-Naggar et al.

Table 7. Effect of seaweed extract, dry yeast treatments and their combinations on leaves dry weight (g) of Ocimum basilicum plants in the first season (2017).

\begin{tabular}{|c|c|c|c|c|c|c|}
\hline \multirow{2}{*}{ Dry yeast (A) g/l } & \multicolumn{5}{|c|}{ Seaweed extract (B) g/l } & \multirow{2}{*}{ Mean } \\
\hline & $\mathbf{0}$ & 1 & 2 & 3 & 4 & \\
\hline \multicolumn{7}{|c|}{ First cut } \\
\hline $\mathbf{0}$ & 3.77 & 3.51 & 4.22 & 3.44 & 3.74 & 3.73 \\
\hline 2 & 3.23 & 4.07 & 3.40 & 4.25 & 4.20 & 3.83 \\
\hline 4 & 4.79 & 4.08 & 4.89 & 4.38 & 4.23 & 4.47 \\
\hline 6 & 4.51 & 4.81 & 4.34 & 4.80 & 5.60 & 4.81 \\
\hline Mean & 4.07 & 4.12 & 4.21 & 4.22 & 4.44 & \\
\hline L.S.D 0.05 & \multicolumn{2}{|c|}{$A=0.313$} & \multicolumn{2}{|c|}{$B=N . S$} & \multicolumn{2}{|c|}{$\mathrm{A} \times \mathrm{B}=0.566$} \\
\hline \multicolumn{7}{|c|}{ Second cut } \\
\hline $\mathbf{0}$ & 3.54 & 3.29 & 3.23 & 3.06 & 3.40 & 3.30 \\
\hline 2 & 3.70 & 3.55 & 4.03 & 3.37 & 3.33 & 3.59 \\
\hline 4 & 3.46 & 4.01 & 3.94 & 3.55 & 3.78 & 3.75 \\
\hline 6 & 4.08 & 4.13 & 3.87 & 5.13 & 5.35 & 4.51 \\
\hline Mean & 3.69 & 3.74 & 3.77 & 3.78 & 3.97 & \\
\hline L.S.D 0.05 & \multicolumn{2}{|c|}{$A=0.308$} & \multicolumn{2}{|c|}{$B=N . S$} & \multicolumn{2}{|c|}{$\mathrm{A} \times \mathrm{B}=0.547$} \\
\hline
\end{tabular}

N.S = Not significant at the level of probability of 0.05 .

Table 8. Effect of seaweed extract, dry yeast treatments and their combinations on leaves dry weight (g) of Ocimum basilicum plants in the second season (2018).

\begin{tabular}{|c|c|c|c|c|c|c|}
\hline \multirow{2}{*}{ Dry yeast (A) g/l } & \multicolumn{5}{|c|}{ Seaweed extract (B) g/l } & \multirow{2}{*}{ Mean } \\
\hline & $\mathbf{0}$ & 1 & 2 & 3 & 4 & \\
\hline \multicolumn{7}{|c|}{ First cut } \\
\hline $\mathbf{0}$ & 3.65 & 4.81 & 3.72 & 4.60 & 4.75 & 4.31 \\
\hline 2 & 4.36 & 3.77 & 4.66 & 5.92 & 4.23 & 4.59 \\
\hline 4 & 4.93 & 4.26 & 5.49 & 4.53 & 5.35 & 4.91 \\
\hline 6 & 4.96 & 5.39 & 4.99 & 5.08 & 6.82 & 5.45 \\
\hline Mean & 4.47 & 4.56 & 4.71 & 5.03 & 5.29 & \\
\hline L.S.D 0.05 & \multicolumn{2}{|c|}{$A=0.399$} & \multicolumn{2}{|c|}{$B=0.414$} & \multicolumn{2}{|c|}{$\mathrm{A} \times \mathrm{B}=0.829$} \\
\hline \multicolumn{7}{|c|}{ Second cut } \\
\hline $\mathbf{0}$ & 3.15 & 4.70 & 4.77 & 4.52 & 5.41 & 4.51 \\
\hline 2 & 5.40 & 4.31 & 4.12 & 4.82 & 4.35 & 4.60 \\
\hline 4 & 3.46 & 3.69 & 5.65 & 4.95 & 5.29 & 4.61 \\
\hline 6 & 4.50 & 4.34 & 5.36 & 6.01 & 6.34 & 5.31 \\
\hline Mean & 4.13 & 4.26 & 4.98 & 5.08 & 5.35 & \\
\hline L.S.D 0.05 & \multicolumn{2}{|c|}{$A=0.226$} & \multicolumn{2}{|c|}{$B=0.477$} & \multicolumn{2}{|c|}{$\mathrm{A} \times \mathrm{B}=0.954$} \\
\hline
\end{tabular}


Table 9. Effect of seaweed extract, dry yeast treatments and their combinations on the leaf area/plant $\left(\mathrm{cm}^{2}\right)$ of Ocimum basilicum plants in the first season (2017).

\begin{tabular}{|c|c|c|c|c|c|c|}
\hline \multirow{2}{*}{ Dry yeast (A) g/l } & \multicolumn{5}{|c|}{ Seaweed extract (B) g/l } & \multirow{2}{*}{ Mean } \\
\hline & $\mathbf{0}$ & 1 & 2 & 3 & 4 & \\
\hline \multicolumn{7}{|c|}{ First cut } \\
\hline $\mathbf{0}$ & 1204.35 & 1219.61 & 1266.90 & 1383.33 & 1257.80 & 1266.40 \\
\hline 2 & 1367.64 & 1429.93 & 1086.78 & 1185.06 & 1378.38 & 1289.56 \\
\hline 4 & 1356.29 & 1336.95 & 1538.84 & 1572.43 & 1326.61 & 1426.23 \\
\hline 6 & 1479.62 & 1627.39 & 1735.65 & 1529.94 & 1784.27 & 1631.37 \\
\hline Mean & 1351.98 & 1403.47 & 1407.04 & 1417.69 & 1436.77 & \\
\hline L.S.D 0.05 & \multicolumn{2}{|c|}{$A=105.333$} & \multicolumn{2}{|c|}{$B=N . S$} & \multicolumn{2}{|c|}{$A \times B=150.916$} \\
\hline \multicolumn{7}{|c|}{ Second cut } \\
\hline $\mathbf{0}$ & 862.24 & 865.53 & 1127.75 & 830.01 & 1056.24 & 948.35 \\
\hline 2 & 960.84 & 1091.21 & 1182.80 & 1017.21 & 1123.54 & 1075.12 \\
\hline 4 & 1116.59 & 1207.07 & 913.30 & 1188.18 & 1059.73 & 1096.97 \\
\hline 6 & 1094.52 & 1245.24 & 1281.52 & 1475.32 & 1385.37 & 1296.39 \\
\hline Mean & 1008.55 & 1102.26 & 1126.34 & 1127.68 & 1156.22 & \\
\hline L.S.D 0.05 & \multicolumn{2}{|c|}{$A=130.007$} & \multicolumn{2}{|c|}{$B=80.265$} & \multicolumn{2}{|c|}{$\mathrm{A} \times \mathrm{B}=160.529$} \\
\hline
\end{tabular}

N.S = Not significant at the level of probability of 0.05 .

Table 10. Effect of seaweed extract, dry yeast treatments and their combinations on the leaf area/plant $\left(\mathrm{cm}^{2}\right)$ of Ocimum basilicum plants in the second season (2018).

\begin{tabular}{|c|c|c|c|c|c|c|}
\hline \multirow{2}{*}{ Dry yeast (A) g/l } & \multicolumn{5}{|c|}{ Seaweed extract (B) g/l } & \multirow{2}{*}{ Mean } \\
\hline & $\mathbf{0}$ & 1 & 2 & 3 & 4 & \\
\hline \multicolumn{7}{|c|}{ First cut } \\
\hline $\mathbf{0}$ & 752.27 & 991.42 & 766.98 & 947.32 & 978.98 & 887.39 \\
\hline 2 & 897.04 & 777.26 & 959.14 & 1218.28 & 870.93 & 944.53 \\
\hline 4 & 1014.74 & 877.20 & 1130.45 & 933.89 & 1101.93 & 1011.64 \\
\hline 6 & 1021.83 & 1111.04 & 1027.19 & 1046.22 & 1404.90 & 1122.24 \\
\hline Mean & 921.47 & 939.23 & 970.94 & 1036.43 & 1089.19 & \\
\hline L.S.D 0.05 & \multicolumn{2}{|c|}{$A=82.183$} & \multicolumn{2}{|c|}{$\mathrm{B}=85.350$} & \multicolumn{2}{|c|}{$A \times B=170.699$} \\
\hline \multicolumn{7}{|c|}{ Second cut } \\
\hline $\mathbf{0}$ & 951.20 & 1417.83 & 1439.22 & 1365.34 & 1633.07 & 1361.33 \\
\hline 2 & 1630.59 & 1299.73 & 1244.35 & 1454.81 & 1313.52 & 1388.6 \\
\hline 4 & 1044.38 & 1115.02 & 1706.84 & 1493.35 & 1597.93 & 1391.51 \\
\hline 6 & 1358.78 & 1309.11 & 1618.29 & 1814.95 & 1914.66 & 1603.16 \\
\hline Mean & 1246.24 & 1285.42 & 1502.18 & 1532.11 & 1614.80 & \\
\hline L.S.D ${ }_{0.05}$ & \multicolumn{2}{|c|}{$A=68.158$} & \multicolumn{2}{|c|}{$B=144.059$} & \multicolumn{2}{|c|}{$\mathrm{A} \times \mathrm{B}=288.118$} \\
\hline
\end{tabular}




\section{A.H. El-Naggar et al.}

for all concentrations in the two seasons except for the first cut of the first season compared with unsprayed plants. The largest leaf area was obtained with spraying the plants with level of $4 \mathrm{~g} / \mathrm{l}$ seaweed (1156.22, 1089.19 and $1614.80 \quad \mathrm{~cm}^{2} /$ plant) respectively, compared with control plants (1008.55, 921.47 and $1246.24 \mathrm{~cm}^{2} /$ plant), respectively. On the other side, the first cut of the first season has the similar trend of the results but without significant difference among treatment.

Concerning the interaction between dry yeast and seaweed treatments, there were significant effects on leaf area in the two cuts of the two seasons. Generally, the greatest area was obtained with treated plants by $6 \mathrm{~g} / \mathrm{l}$ dry yeast with $4 \mathrm{~g} / \mathrm{l}$ seaweed (1784.27, $1475.32,1404.90$ and $1914.66 \mathrm{~cm}^{2} /$ plant) for the first and the second seasons, respectively. The lowest area was obtained with treated plants by $2 \mathrm{~g} / \mathrm{l}$ dry yeast $+2 \mathrm{~g} / \mathrm{l}$ seaweed with value of $1086.78 \mathrm{~cm}^{2} /$ plant in the first cut of the first season. While in the second cut of the first season the lowest area was obtained by using control dry yeast $+3 \mathrm{~g} / \mathrm{l}$ seaweed with a value of $830.01 \mathrm{~cm}^{2} /$ plant. In the second season, the lowest area was obtained with untreated plants by control dry yeast + control seaweed with values of 752.27 and $951.20 \mathrm{~cm}^{2} /$ plant, respectively for both cuts.

These results may be due to the physiological roles of cytokinins, vitamins and amino acids in the yeast which increased the metabolic processes and levels of endogenous hormones, i.e., IAA and $\mathrm{GA}_{3}$ (Chaliakhyan, 1957; Muller and Leopold, 1966). These previous results were in agreement with those obtained by Nofal et al. (2015) on Calendula officinalis.

Effect of seaweed extract and dry yeast on the chemical constituents of Ocimum basilicum plants:

\section{Oil percentage (\%):}

From the data in Tables (11 and 12) it is clear that there was significant effect of all levels of dry yeast treatments on oil percentage of basil in both harvesting in the both seasons compared with untreated plants. The highest values were obtained by the treatment of $6 \mathrm{~g} / \mathrm{l}$ with values of $(0.128$, $0.182,0.151$ and $0.195 \%$ ) in both cuts in the both seasons, respectively compared with the control plants $(0.103,0.141,0.131$ and $0.126 \%$ ), respectively. Moreover, there was no significant effect between the levels of 2 , 4 and $6 \mathrm{~g} / \mathrm{l}$ in the first cut of the second season. Furthermore, the treated basil plants with seaweed showed a regular increase in essential oil percentage for the two cuts of the two seasons. The highest value was obtained with spraying with $4 \mathrm{~g} / \mathrm{l}$ seaweed (0.129, 0.173, 0.163 and $0.164 \%$ ), compared with control plants $(0.109,0.134,0.125$ and $0.133 \%)$, respectively.

The interaction between dry yeast and seaweed treatments for essential oil percentage gave a regular increase for the both cuts of the both seasons. The highest value was obtained with spraying plants with $4 \mathrm{~g} / \mathrm{l}$ dry yeast $+4 \mathrm{~g} / \mathrm{l}$ seaweed $(0.155$ and $0.180 \%$ ) respectively, for the first cut of the first and second seasons, and spraying plants with $6 \mathrm{~g} / \mathrm{l}$ dry yeast $+2 \mathrm{~g} / \mathrm{l}$ seaweed $(0.212 \%)$ for the second cut of the first season, and spraying plants with $6 \mathrm{~g}$ dry yeast $+4 \mathrm{~g} / \mathrm{l}$ seaweed $(0.330 \%)$ for the second cut of the second season. The increase in oil yield may be due to increase the number of leaves and leaf area to the role of cytokinins in increasing monoterpene biosynthesis and increasing the number of oil glands or enlargement in oil glands or bath. Similar results were found by Kassem (2013) on rosemary, and Omer et al. (2016) on Ocimum basilicum.

\section{Oil yield (ml/plant):}

Data in Tables (13 and 14) showed that the oil yield (ml/plant) of basil plants were significantly affected by treating plants with all levels of dry yeast in two cuts of the two seasons compared with control treatment. The best results were obtained from treating plants with dry yeast at rate of $6 \mathrm{~g} / \mathrm{l}$ with values of (0.0296, 0.0476, 0.0406 and 0.0586 $\mathrm{ml} / \mathrm{plant}$ ) in both cuts in the both seasons compared with the control, respectively. 
Table 11. Effect of seaweed extract, dry yeast treatments and their combinations on oil percentage (\%) of Ocimum basilicum plants in the first season (2017).

\begin{tabular}{|c|c|c|c|c|c|c|}
\hline \multirow{2}{*}{ Dry yeast (A) g/l } & \multicolumn{5}{|c|}{ Seaweed extract (B) g/l } & \multirow{2}{*}{ Mean } \\
\hline & $\mathbf{0}$ & 1 & 2 & 3 & 4 & \\
\hline \multicolumn{7}{|c|}{ First cut } \\
\hline $\mathbf{0}$ & 0.098 & 0.118 & 0.106 & 0.114 & 0.079 & 0.103 \\
\hline 2 & 0.113 & 0.118 & 0.115 & 0.121 & 0.126 & 0.119 \\
\hline 4 & 0.105 & 0.118 & 0.133 & 0.107 & 0.155 & 0.124 \\
\hline 6 & 0.120 & 0.103 & 0.125 & 0.140 & 0.154 & 0.128 \\
\hline Mean & 0.109 & 0.114 & 0.120 & 0.120 & 0.129 & \\
\hline L.S.D 0.05 & \multicolumn{2}{|c|}{$\mathrm{A}=0.008$} & \multicolumn{2}{|c|}{$\mathrm{B}=0.009$} & \multicolumn{2}{|c|}{$\mathrm{A} \times \mathrm{B}=0.019$} \\
\hline \multicolumn{7}{|c|}{ Second cut } \\
\hline $\mathbf{0}$ & 0.120 & 0.165 & 0.124 & 0.130 & 0.166 & 0.141 \\
\hline 2 & 0.157 & 0.143 & 0.146 & 0.124 & 0.177 & 0.149 \\
\hline 4 & 0.106 & 0.165 & 0.147 & 0.176 & 0.154 & 0.150 \\
\hline 6 & 0.154 & 0.139 & 0.212 & 0.210 & 0.194 & 0.182 \\
\hline Mean & 0.134 & 0.153 & 0.157 & 0.160 & 0.173 & \\
\hline L.S.D 0.05 & \multicolumn{2}{|c|}{$A=0.014$} & \multicolumn{2}{|c|}{$B=0.025$} & \multicolumn{2}{|c|}{$\mathrm{A} \times \mathrm{B}=0.050$} \\
\hline
\end{tabular}

Table 12. Effect of seaweed extract, dry yeast treatments and their combinations on oil percentage (\%) of Ocimum basilicum plants in the second season (2018).

\begin{tabular}{|c|c|c|c|c|c|c|}
\hline \multirow{2}{*}{ Dry yeast (A) g/l } & \multicolumn{5}{|c|}{ Seaweed extract (B) g/l } & \multirow{2}{*}{ Mean } \\
\hline & $\mathbf{0}$ & 1 & 2 & 3 & 4 & \\
\hline \multicolumn{7}{|c|}{ First cut } \\
\hline $\mathbf{0}$ & 0.120 & 0.147 & 0.120 & 0.110 & 0.160 & 0.131 \\
\hline 2 & 0.120 & 0.140 & 0.170 & 0.160 & 0.140 & 0.146 \\
\hline 4 & 0.140 & 0.113 & 0.140 & 0.160 & 0.180 & 0.147 \\
\hline 6 & 0.120 & 0.160 & 0.133 & 0.170 & 0.173 & 0.151 \\
\hline Mean & 0.125 & 0.140 & 0.141 & 0.150 & 0.163 & \\
\hline L.S.D 0.05 & \multicolumn{2}{|c|}{$A=0.013$} & \multicolumn{2}{|c|}{$\mathrm{B}=0.014$} & \multicolumn{2}{|c|}{$\mathrm{A} \times \mathrm{B}=0.028$} \\
\hline \multicolumn{7}{|c|}{ Second cut } \\
\hline $\mathbf{0}$ & 0.122 & 0.126 & 0.185 & 0.091 & 0.104 & 0.126 \\
\hline 2 & 0.175 & 0.125 & 0.093 & 0.178 & 0.088 & 0.132 \\
\hline 4 & 0.088 & 0.181 & 0.154 & 0.209 & 0.135 & 0.153 \\
\hline 6 & 0.146 & 0.171 & 0.179 & 0.150 & 0.330 & 0.195 \\
\hline Mean & 0.133 & 0.151 & 0.153 & 0.157 & 0.164 & \\
\hline L.S.D 0.05 & \multicolumn{2}{|c|}{$A=0.029$} & \multicolumn{2}{|c|}{$\mathrm{B}=0.019$} & \multicolumn{2}{|c|}{$\mathrm{A} \times \mathrm{B}=0.038$} \\
\hline
\end{tabular}


A.H. El-Naggar et al.

Table 13. Effect of seaweed extract, dry yeast treatments and their combinations on oil yield (ml/plant) of Ocimum basilicum plants in the first season (2017).

\begin{tabular}{|c|c|c|c|c|c|c|}
\hline \multirow{2}{*}{ Dry yeast (A) g/l } & \multicolumn{5}{|c|}{ Seaweed extract (B) g/l } & \multirow{2}{*}{ Mean } \\
\hline & $\mathbf{0}$ & 1 & 2 & 3 & 4 & \\
\hline \multicolumn{7}{|c|}{ First cut } \\
\hline $\mathbf{0}$ & 0.0176 & 0.0197 & 0.0213 & 0.0186 & 0.0141 & 0.0182 \\
\hline 2 & 0.0174 & 0.0228 & 0.0186 & 0.0245 & 0.0252 & 0.0217 \\
\hline 4 & 0.0239 & 0.0229 & 0.0309 & 0.0223 & 0.0312 & 0.0263 \\
\hline 6 & 0.0257 & 0.0236 & 0.0258 & 0.0320 & 0.0410 & 0.0296 \\
\hline Mean & 0.0211 & 0.0223 & 0.0242 & 0.0243 & 0.0279 & \\
\hline L.S.D 0.05 & \multicolumn{2}{|c|}{$\mathrm{A}=0.002$} & \multicolumn{2}{|c|}{$B=0.002$} & \multicolumn{2}{|c|}{$\mathrm{A} \times \mathrm{B}=0.004$} \\
\hline \multicolumn{7}{|c|}{ Second cut } \\
\hline $\mathbf{0}$ & 0.0244 & 0.0312 & 0.0230 & 0.0229 & 0.0325 & 0.0268 \\
\hline 2 & 0.0334 & 0.0292 & 0.0338 & 0.0240 & 0.0339 & 0.0309 \\
\hline 4 & 0.0211 & 0.0380 & 0.0333 & 0.0360 & 0.0335 & 0.0324 \\
\hline 6 & 0.0361 & 0.0330 & 0.0471 & 0.0620 & 0.0597 & 0.0476 \\
\hline Mean & 0.0288 & 0.0329 & 0.0343 & 0.0362 & 0.0399 & \\
\hline L.S.D 0.05 & \multicolumn{2}{|c|}{$A=0.004$} & \multicolumn{2}{|c|}{$\mathrm{B}=0.005$} & \multicolumn{2}{|c|}{$\mathrm{A} \times \mathrm{B}=0.011$} \\
\hline
\end{tabular}

Table 14. Effect of seaweed extract, dry yeast treatments and their combinations on oil yield (ml/plant) of Ocimum basilicum plants in the second season (2018).

\begin{tabular}{|c|c|c|c|c|c|c|}
\hline \multirow{2}{*}{ Dry yeast (A) g/l } & \multicolumn{5}{|c|}{ Seaweed extract (B) g/l } & \multirow{2}{*}{ Mean } \\
\hline & $\mathbf{0}$ & 1 & 2 & 3 & 4 & \\
\hline \multicolumn{7}{|c|}{ First cut } \\
\hline $\mathbf{0}$ & 0.0213 & 0.0344 & 0.0218 & 0.0246 & 0.0370 & 0.0278 \\
\hline 2 & 0.0254 & 0.0257 & 0.0385 & 0.0461 & 0.0288 & 0.0329 \\
\hline 4 & 0.0336 & 0.0234 & 0.0374 & 0.0353 & 0.0469 & 0.0353 \\
\hline 6 & 0.0290 & 0.0420 & 0.0323 & 0.0420 & 0.0575 & 0.0406 \\
\hline Mean & 0.0273 & 0.0314 & 0.0325 & 0.0370 & 0.0425 & \\
\hline L.S.D 0.05 & \multicolumn{2}{|c|}{$A=0.004$} & \multicolumn{2}{|c|}{$B=0.004$} & \multicolumn{2}{|c|}{$\mathrm{A} \times \mathrm{B}=0.008$} \\
\hline \multicolumn{7}{|c|}{ Second cut } \\
\hline $\mathbf{0}$ & 0.0210 & 0.0324 & 0.0482 & 0.0225 & 0.0308 & 0.0310 \\
\hline 2 & 0.0517 & 0.0294 & 0.0210 & 0.0469 & 0.0209 & 0.0340 \\
\hline 4 & 0.0166 & 0.0366 & 0.0476 & 0.0566 & 0.0391 & 0.0393 \\
\hline 6 & 0.0359 & 0.0406 & 0.0525 & 0.0493 & 0.1145 & 0.0586 \\
\hline Mean & 0.0313 & 0.0347 & 0.0423 & 0.0438 & 0.0513 & \\
\hline L.S.D 0.05 & \multicolumn{2}{|c|}{$\mathrm{A}=0.010$} & \multicolumn{2}{|c|}{$\mathrm{B}=0.008$} & \multicolumn{2}{|c|}{$\mathrm{A} \times \mathrm{B}=0.015$} \\
\hline
\end{tabular}


For the seaweed treatments, the best results were obtained with spraying the plants with level of $4 \mathrm{~g} / \mathrm{l}$ seaweed $(0.0279$, $0.0399, \quad 0.0425$ and $0.0513 \mathrm{ml} /$ plant) respectively, compared with control plants (0.0211, $0.0288, \quad 0.0273$ and 0.0313 $\mathrm{ml} /$ plant), respectively.

The interaction between dry yeast and seaweed treatments for fresh leaves content of essential oil per plant gave increase for the both seasons except of the second cut of the first season. The highest value was obtained with spraying plants with $6 \mathrm{~g} / \mathrm{l}$ dry yeast +3 $\mathrm{g} / \mathrm{l}$ seaweed $(0.0320$ and $0.0620 \mathrm{ml} / \mathrm{plant})$ for the two cuts of the first season, and spraying plants with $6 \mathrm{~g} / \mathrm{l}$ dry yeast $+4 \mathrm{~g} / \mathrm{l}$ seaweed ( 0.0575 and $0.1145 \mathrm{ml} / \mathrm{plant}$ ) for the two cuts of the second season. On the other side, the lowest values there were no constant trend.

This increasing in the oil yield could be due to the increase in the leaf area, number of leaves. The results obtained here confirm those of Zakria (2014) on rosemary.

\section{Essential oil Composition (\%)}

According to GC/MS analysis of essential oil of Ocimum basilicum fresh leaves which were grown under different foliar dry yeast and seaweed treatments concentration as presented in Table (15), nineteen compounds were identified in the essential oil of sweet basil plants in the second cut of the second season.

The major compounds were Linalool, Estragole (Methyl Chavicol), Eucalyptol (1,8-cineole), Methyl cinnamate, Taucadinol, Trans- $\alpha$-Bergamotene and Bornyl acetate. Table (15) presented the values of the 19 components as affected by different dry yeast and seaweed treatments and their combinations. The major components were Linalool which ranged from (52.16-79.55\%) the highest percentage was obtained by treatment of $6 \mathrm{~g} / \mathrm{l}$ dry yeast with $0 \mathrm{~g} / \mathrm{l}$ seaweed followed by the treatment of $6 \mathrm{~g} / \mathrm{l}$ dry yeast with $4 \mathrm{~g} / \mathrm{l}$ seaweed (74.94\%). Estragole ranged from (5.14-11.79\%) the highest percentage was obtained by treatment of $6 \mathrm{~g} / \mathrm{l}$ dry yeast with $1 \mathrm{~g} / \mathrm{l}$ seaweed followed by the treatment of $6 \mathrm{~g} / \mathrm{l}$ dry yeast with $3 \mathrm{~g} / \mathrm{l}$ seaweed (10.95\%). Eucalyptol ranged from (1.54-9.72\%) the highest percentage was obtained by treatment of $4 \mathrm{~g} / \mathrm{l}$ dry yeast with $2 \mathrm{~g} / \mathrm{l}$ seaweed followed by the treatment of $2 \mathrm{~g} / \mathrm{l}$ dry yeast with $0 \mathrm{~g} / \mathrm{l}$ seaweed (control) (6.89\%). Methyl cinnamate ranged from $(1.12-10.37 \%)$ the highest percentage was obtained by treatment of $0 \mathrm{~g} / \mathrm{l}$ dry yeast (control) with $4 \mathrm{~g} / \mathrm{l}$ seaweed followed by the treatment of $2 \mathrm{~g} / \mathrm{l}$ dry yeast with $3 \mathrm{~g} / \mathrm{l}$ seaweed $(9.99 \%)$. Tau-cadinol ranged from (1.01-6.97\%) the highest percentage was obtained by treatment of $2 \mathrm{~g} / \mathrm{l}$ dry yeast with $2 \mathrm{~g} / \mathrm{l}$ seaweed followed by the treatment of 0 $\mathrm{g} / \mathrm{l}$ dry yeast (control) with $1 \mathrm{~g} / \mathrm{l}$ seaweed (5.58\%). Trans- $\alpha$-Bergamotene ranged from (1.23-5.18 \%) the highest percentage was obtained by treatment of $0 \mathrm{~g} / \mathrm{l}$ dry yeast (control) with $0 \quad \mathrm{~g} / \mathrm{l}$ seaweed (control) followed by the treatment of $3 \mathrm{~g} / \mathrm{l}$ dry yeast with $2 \mathrm{~g} / \mathrm{l}$ seaweed (5.09\%). Bornyl acetate ranged from (1.12-4.53\%) the highest percentage was obtained by treatment of 2 $\mathrm{g} / \mathrm{l}$ dry yeast with $4 \mathrm{~g} / \mathrm{l}$ seaweed followed by the treatment of $4 \mathrm{~g} / \mathrm{l}$ dry yeast with $4 \mathrm{~g} / \mathrm{l}$ seaweed (3.78\%).

Eugenol ranged from (1.17-9.57\%) the highest percentage was obtained by treatment of $4 \mathrm{~g} / \mathrm{l}$ dry yeast with $1 \mathrm{~g} / \mathrm{l}$ seaweed followed by the treatment of $4 \mathrm{~g} / \mathrm{l}$ dry yeast with $0 \mathrm{~g} / \mathrm{l}$ seaweed (control) (5.61\%). The p-menth-1-en-4-ol(terpinen-4ol) ranged from (0.40-3.79\%) the highest percentage was obtained by treatment of 2 $\mathrm{g} / \mathrm{l}$ dry yeast with $0 \mathrm{~g} / \mathrm{l}$ seaweed (control) followed by the treatment of $6 \mathrm{~g} / \mathrm{l}$ dry yeast with $3 \mathrm{~g} / \mathrm{l}$ seaweed (2.41\%). Ocimene ranged from $(0.24-2.47 \%)$ the highest percentage was obtained by treatment of $2 \mathrm{~g} / \mathrm{l}$ dry yeast with $3 \mathrm{~g} / \mathrm{l}$ seaweed followed by the treatment of $4 \mathrm{~g} / \mathrm{l}$ dry yeast with $2 \mathrm{~g} / \mathrm{l}$ seaweed (1.22\%). Methyl eugenol ranged from (0.50$2.00 \%$ ) the highest percentage was obtained by treatment of $6 \mathrm{~g} / \mathrm{l}$ dry yeast with $3 \mathrm{~g} / \mathrm{l}$ seaweed followed by the treatment of $0 \mathrm{~g} / \mathrm{l}$ dry yeast (control) with $3 \mathrm{~g} / \mathrm{l}$ seaweed (1.08\%). 


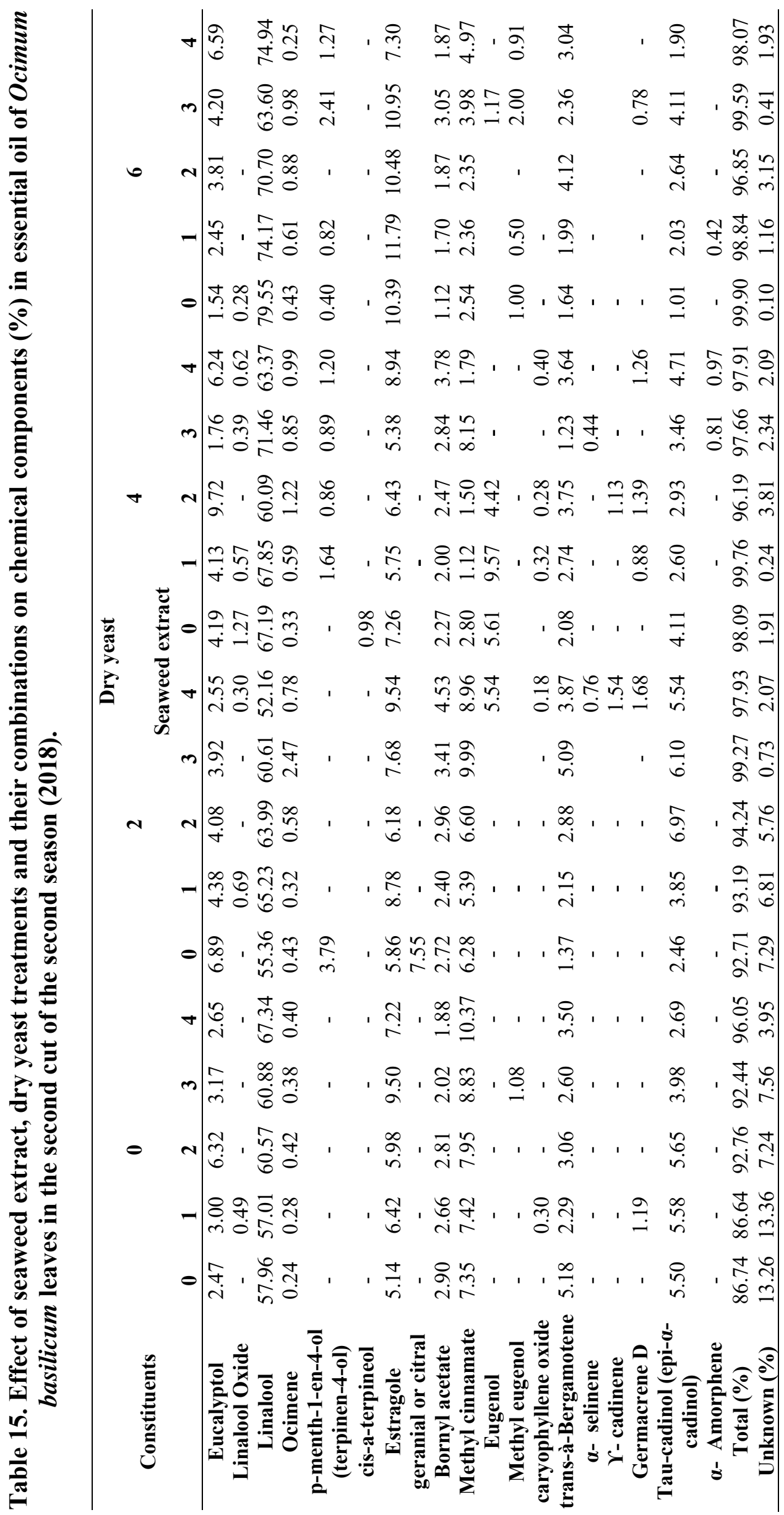


Germacrene D ranged from (0.78$1.68 \%)$ the highest percentage was obtained by treatment of $2 \mathrm{~g} / \mathrm{l}$ dry yeast with $4 \mathrm{~g} / \mathrm{l}$ seaweed followed by the treatment of $4 \mathrm{~g} / \mathrm{l}$ dry yeast with $2 \mathrm{~g} / \mathrm{l}$ seaweed (1.39\%). Linalool Oxide ranged from (0.28-1.27\%) the highest percentage was obtained by treatment of $4 \mathrm{~g} / \mathrm{l}$ dry yeast with $0 \mathrm{~g} / \mathrm{l}$ seaweed (control) followed by the treatment of $2 \mathrm{~g} / \mathrm{l}$ dry yeast with $1 \mathrm{~g} / \mathrm{l}$ seaweed $(0.69 \%)$. The $\alpha$-Amorphene ranged from $(0.42-0.97 \%)$ the highest percentage was obtained by treatment of $4 \mathrm{~g} / \mathrm{l}$ dry yeast with $4 \mathrm{~g} / \mathrm{l}$ seaweed followed by the treatment of 4 $\mathrm{g} / \mathrm{l}$ dry yeast with $3 \mathrm{~g} / \mathrm{l}$ seaweed $(0.81 \%)$. Caryophyllene oxide ranged from (0.18$0.40 \%$ ) the highest percentage was obtained by treatment of $4 \mathrm{~g} / \mathrm{l}$ dry yeast with $4 \mathrm{~g} / \mathrm{l}$ seaweed followed by the treatment of $4 \mathrm{~g} / \mathrm{l}$ dry yeast with $1 \mathrm{~g} / \mathrm{l}$ seaweed $(0.32 \%)$. The $\gamma$ cadinene $(1.54 \%$ was produced only by treatment of $2 \mathrm{~g} / \mathrm{l}$ dry yeast with $4 \mathrm{~g} / \mathrm{l}$ seaweed, and $1.13 \%$ by treatment of $4 \mathrm{~g} / \mathrm{l}$ dry yeast with $2 \mathrm{~g} / \mathrm{l}$ seaweed). The $\alpha$-selinene $(0.76 \%)$ was produced only by treatment of 2 $\mathrm{g} / \mathrm{l}$ dry yeast with $4 \mathrm{~g} / \mathrm{l}$ seaweed, and $0.44 \%$ by treatment of $4 \mathrm{~g} / \mathrm{l}$ dry yeast with $3 \mathrm{~g} / \mathrm{l}$ seaweed. Citral (7.55\%) was produced only by treatment of $2 \mathrm{~g} / \mathrm{l}$ dry yeast with $0 \mathrm{~g} / \mathrm{l}$ seaweed (control). The cis-a-terpineol $(0.98 \%)$ was produced only by treatment of 4 $\mathrm{g} / \mathrm{l}$ dry yeast with $0 \mathrm{~g} / \mathrm{l}$ seaweed (control). These increases in oil components may be due to the cytokinins plays a role in increasing monoterpene biosynthesis, and these factors could cause an increase in the essential oil component (Gershenzon et al., 2002).

These results are in a good agreement with those of Zheljazkov et al. (2008) and Chenni et al. (2016) on Ocimum basilicum, L.

\section{REFERENCES}

Ahmed, M. and Kibret, M. (2014). Mechanisms and applications of plant growth promoting rhizobacteria: Current perspective. Journal of King Saud University-Science, 26:1-20.
Battacharyya, D.; Babgohari, M.Z.; Rathor, P. and Prithiviraj, B. (2015). Seaweed extracts as biostimulants in horticulture. Scientia Horticulturae,196:39-48.

Bilal, A.; Jahan, N.; Ahmed, A.; Bilal, S.N., Habib, S. and Hajra, S. (2012). Phytochemical and pharmocologihcal studies on Ocimum basilicum Linn - A Review. International Journal of Current Research and Review, 4(23):73-83.

Chaliakhyan, M. Kh. (1957). Effect of vitamins on growth and development of plants. Dokly Akad. Nauk. SSSK 111:894-897.

Charles, D.J. and Simon, J.E. (1990). Comparison of extraction methods for the rapid determination of essential oil content and composition of basil (Ocimum spp.). Journal of the American Society for Horticultural Science, 115(3):458-462.

Chenni, M.; El Abed, D., Rakotomanomana, N.; Fernandez, X. and Chemat, F. (2016). Comparative study of essential oils extracted from Egyptian basil leaves (Ocimum basilicum L.) using hydrodistillation and solvent-free microwave extraction. Molecules, 113:1-16.

Gershenzon, J.; Conkey, M. and Croteau. R. (2002). Biochemical molecular regulation of monoterpene accumulation in peppermint. Journal of Herbs, Spices and Medicinal Plants, 9 (2/3):153-156.

Gomez, K.K. and Gomez, A.A. (1984). Statistical Procedures for Agricultural Research, $2^{\text {nd }}$ Ed. John Wiley and sons, New York, USA, 680 p.

Kassem, A.H.M. (2013). Effect of dry yeast and whey applications on herb growth and essential oil yield of rosemary. Journal of Productivity and Development (Agricultural Research), 18(3):421-463.

Khedr, Z.M. and Farid, S. (2002). Response of naturally virus infected-tomato plants to yeast extract and phosphoric acid application. Ann. Agric. Sci. Moshtohor, Egypt, 38(2):927-939. 


\section{A.H. El-Naggar et al.}

Moghith, W.M. (2016). Effect of Organic and Biofertilization on the Growth, Production and the Chemical Constituents of Origanum vulgare L. Plants. M.Sc. Thesis, Fac. Agric., Tanta Univ., Egypt 116 p.

Mohamed, M.E.A. (2015). Effect of Mineral, Organic and Biofertilizers on Vegetative Growth and Oil Yield of Ocimum basillicum, L. Plants. Ph.D. Thesis, Fac. Agric., Alexandria University. Egypt, $176 \mathrm{p}$.

Mohamed, Y.F.Y.; Zewail, R.M.Y. and Ghatas, Y.A.A. (2016). The role of boron and some growth substances on growth, oil productivity and chemical characterization of volatile oils in basil (Ocimum basilicum L.) cv. Genovese. Journal of Horticultural Science and Ornamental Plants, 8 (2):108-118.

Muller, K. and Leopold, A.C. (1966). Mechanism of kinetin induced transport in corn leaves. Planta, 68:185-205.

Nofal, F.H.; El-Segai, M.U. and Seleem, E.A. (2015). Response of Calendula officinalis L. plants to growth stimulants under salinity stress. American-Eurasian J. Agric. and Environ. Sci., 15(9):17671778.

Novak, J.; Jan, L.; Friedrich, P. and Chlodwig, M.F. (2002). Essential oil compounds in a historical sample of majoram (Origanum majorana L., Lamiaceae). Flavour and Fragrance Journal, 17:175-180.

Omer, E.A.; Hussein M.S.; Osman, A.R.; Sewedan, E.; Elgohary, A.I. and Salman, A. M. (2016). Response of basil essential oil to cultivation date and organic fertilization. International Journal of PharmTech. Research, 9 (5):86-98.

ÖrdÖg, V.; Stirk, W.A.; Van-Staden, J.; Novak, O. and Strnad, M. (2004). Endogenous cytokinins in the three genera of micro algae from the Chlorophyta. Journal of Phycology, 40(1):88-95.
Paton, A.; Harley, R.M. and Harley, M.M. (1999). Ocimum: an overview of relationships and classification, In: Y. Holm and R. Hiltunen, eds. Medicinal and Aromatic Plants-Industrial Profiles. Harwood Academic, Amsterdam, The Netherlands, pp. 1-8.

Pripdeevech, P.; Chumpolsri, W.; Suttiarporn, P. and Wongpornchai, S. (2010). The chemical composition and antioxidant activities of basil from Thailand using retention indices and comprehensive two-dimensional gas chromatography. Journal of the Serbian Chemical Society, 75(11):1503-1513.

Ragab, T.M.E. (2016). Effect of Application of Seaweed Extract on Growth and Quality of Some Ornamental Plants. M.Sc. Thesis, Fac. Agric., Ain Shams University, Egypt, 111 p.

Shalaby, M.E. and El-Nady, M.F. (2008). Application of Saccharomyces cerevisiae as a biocontrol agent against Fusarium infection of sugar beet plants. Acta Biologica Szegediensis, 52(2):271-275.

Sharafzadeh, S. and Alizadeh, O. (2011). Nutrient supply and fertilization of basil. Advances in Environmental Biology, 5(5):956-960.

Sivasangari, R.S.; Vijayan, N. and Rathinavel, S. (2015). Foliar application of liquid biofertilizer of brown alga Stoechospermum marginatum on growth, biochemical and yield of Solanum melongena. Int. J. Recycl Org. Waste in Agriculture, 4:167-173.

Spencer, T.F.T.; Dorothy, S.M. and Smith, A.R.W. (1983). Yeast genetics, fundamental and applied aspects. Springer-Verlag, New York, USA, pp. 618.

Zheljazkov, V.D.; Callahan, A. and Cantrell, C.L. (2008). Yield and oil composition of 38 basil (Ocimum basilicum L.) accessions grown in Mississippi. J. Agric. Food Chem., 56(1):241-245. 
Zakaria, E.A. (2014). Physiological Studies on Rosmary (Rosmarinus officinalis). M.Sc. Thesis, Fac. Science, Helwan University, Egypt.

\section{النمو وتحليل الزيت الطيار لنبات الريحان المتأثر بمستخلصات الأعثاب البحرية والخميرة الجافة علي حسن محمد النجار ، محمد رجب علي حسن، أمل مدنى سعيد قسم الز هور و نباتات الزينة و تنسيق الحدائق، كلية الزر اعة، جامعة الاسكندرية ( الثاطبى)، الاسكندرية، مصر}

أُجريت هذة الدر اسة في مشتل قسم الزهور ونام ونباتات الزينة وتنسيق الحدائق، كلية الزر اعة، جامعة الإسكندرية، خلال

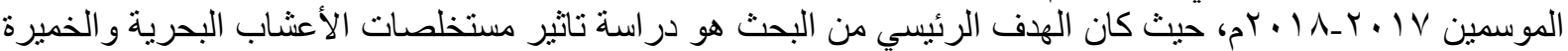

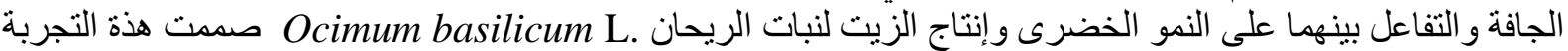

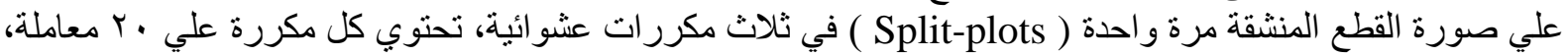

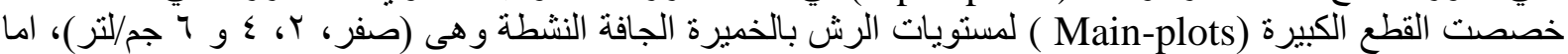

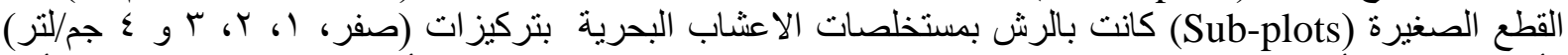

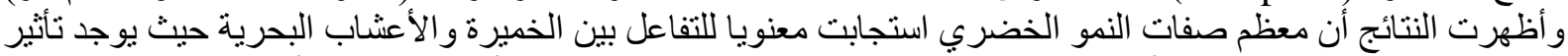

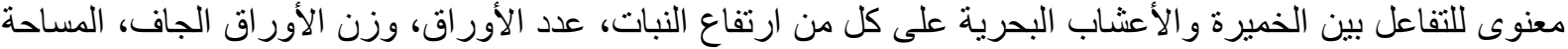

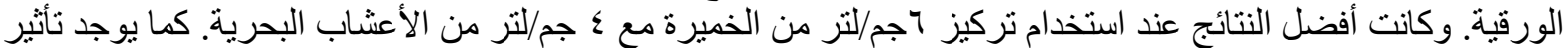

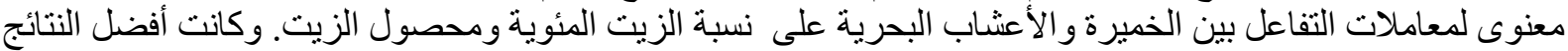

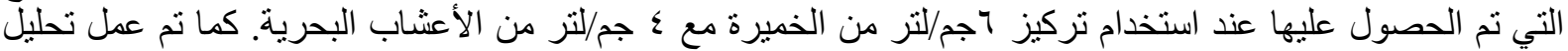

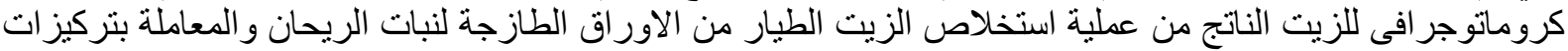

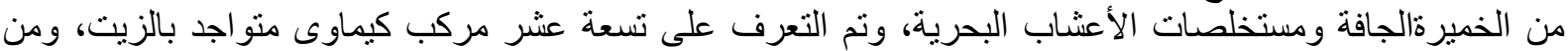

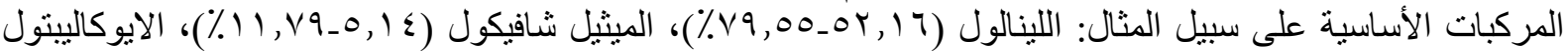

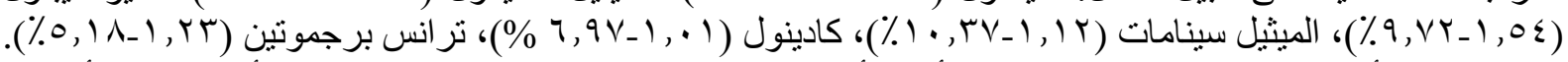

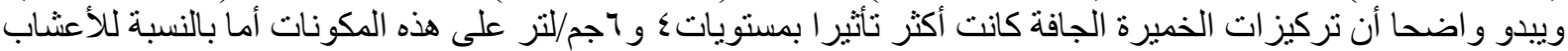
البحرية فتأثير ها متغيير ما بين الصفر و ع عم/لتنر. 